\title{
Foliar Application of Defoliants before Winter Chill Accumulation Advances Budbreak and Improves Fruit Earliness of Blackberry under Subtropical Climatic Conditions
}

\author{
Syuan-You Lin and Shinsuke Agehara \\ Gulf Coast Research and Education Center, Institute of Food and Agricultural \\ Sciences, University of Florida, 14625 CR 672, Wimauma, FL, 33598
}

Additional index words. chilling requirement, defoliation, dormancy, off-season production, plant growth regulator, Rubus

\begin{abstract}
In subtropical blackberry (Rubus L. subgenus Rubus Watson) production, inadequate winter chill causes poor and erratic budbreak, whereas high temperatures and heavy rainfall deteriorate late-season fruit quality. We examined the effects of four defoliants [zinc sulfate (ZS), potassium thiosulfate (KTS), urea, and lime sulfur (LS)] on defoliation, budbreak, yield, and fruit quality of 'Natchez' blackberry grown under inadequate chilling conditions in two consecutive growing seasons. Plants were treated with defoliants at $187 \mathrm{~kg} \cdot \mathrm{ha}^{-1}$ via spray application $\left(1870 \mathrm{~L} \cdot \mathrm{ha}^{-1}\right)$ at the beginning of chill accumulation (late December). A nonionic surfactant (Agri-Dex) was added at $0.5 \%$ $(v / v)$ to all treatments including the water control. Cumulative chilling hours $\left(<7.2{ }^{\circ} \mathrm{C}\right)$ at the experiment site were 209 and 134 in the first and second growing seasons, respectively. Defoliation was only $40.2 \%$ to $55.5 \%$ in the control, but it was induced moderately by LS (69.7\% to $84.7 \%)$ and severely by the other defoliants $(81.7 \%$ to $94.7 \%)$. Budbreak was induced most rapidly by urea application, followed by LS, KTS, and ZS, advancing by 17 to 66 days compared with the control. Consequently, urea, KTS, LS, and ZS increased early season yield by $2.79,2.55,0.87$, and 0.31 t.ha ${ }^{-1}$, respectively, compared with the control $\left(0.12 \mathrm{t}^{\cdot \mathrm{ha}^{-1}}\right)$. By contrast, the final percentage of budbreak and totalseason yield did not show significant treatment effects. KTS caused cane dieback and increased bud mortality, resulting in the lowest total-season yield among the treatments. Importantly, defoliants had no negative impact on berry size and soluble solids concentration. These results suggest that urea, LS, and ZS are effective bud dormancy-breaking agents for blackberry and that they could be an important adaptation tool for subtropical blackberry production. Among the three defoliants, urea appears to be the ideal chemical option because of its consistent efficacy, favorable safety profile, and low application cost.
\end{abstract}

Blackberry (Rubus L. subgenus Rubus Watson) is a deciduous berry crop for which production is expanding worldwide. This trend is

\footnotetext{
Received for publication 22 Oct. 2020. Accepted for publication 24 Nov. 2020.

Published online 31 December 2020.

This study was supported in part by the Florida Specialty Crop Block Grant Program (USDA-AMSSCBGP-2019). We thank Dustin Groom for allowing us to conduct experiments in his orchard and for his cooperation, Dante Pinochet for his assistance during data collection and insightful comments, and all members of Horticultural Crop Physiology Lab at the Gulf Coast Research and Education Center for their technical assistance.

The use of brand names and any mention or listing of commercial products or services in the publication does not imply endorsement by University of Florida nor discrimination against similar products or services not mentioned.

S.A. is the corresponding author. E-mail: sagehara@ ufl.edu.

This is an open access article distributed under the CC BY-NC-ND license (https://creativecommons. org/licenses/by-nc-nd/4.0/).
}

mainly driven by increased consumer demand, improved cultivars, and advanced production methods (Clark and Finn, 2014). The majority of commercial blackberry production is concentrated in temperate regions with cool winter temperatures, such as Serbia, Hungary, the northwestern United States, Mexico, and China (Strik et al., 2007). In the United States, blackberry is the fourth most economically important small fruit crop, generating $\$ 697$ million in retail sales during 2019 (California Strawberry Commission, 2019). California and Oregon are the leading states in fresh-market and processing blackberry production, respectively. Blackberry production has recently expanded to the southeastern states, such as Georgia and Arkansas (Clark and Finn, 2014), where the production acreage increased by 52\% (996 vs. 1512 ha) from 2007 to 2017 [U.S. Department of Agriculture (USDA), 2017]. In Florida, however, the production acreage is still very limited (98 ha) (USDA, 2017), mostly because winter chilling hours are not adequate to break bud dormancy for major blackberry cultivars.

As in most deciduous fruit crops, winter chill plays an important role in budbreak and flower development in blackberry (Takeda et al., 2002). In general, blackberry plants defoliate naturally and develop flower buds on primocanes in late fall. Buds will enter into dormancy during winter, and they will sprout in the upcoming spring. Plants must be exposed to a certain amount of winter chill to break bud dormancy in spring. This socalled chilling requirement is highly variable among blackberry cultivars. The chilling requirement of commercial floricane-fruiting blackberry cultivars varies from 300 to $900 \mathrm{~h}$ below $7.2^{\circ} \mathrm{C}$ (Carter et al., 2006; Drake and Clark, 2000; McWhirt, 2017b). The timing and rate of budbreak are critical to temperate fruit production because they determine the harvest window, yields, and fruit quality (Atkinson et al., 2013). Under insufficient chilling conditions, plants fail to break dormancy, resulting in poor budbreak, abnormal flowering, and ultimately low fruit yields (Fear and Meyer, 1993; Lin and Agehara, 2020a, 2020b).

Despite the rapidly growing demand worldwide, blackberry production is predominant in temperate climates (Clark and Finn, 2014), where winter chill is adequate to meet the chilling requirement. In subtropical climates, blackberry production has two major challenges. First, inadequate chilling causes poor and erratic budbreak. Second, late-season harvests coincide with high temperatures and heavy rainfall, deteriorating fruit quality via sunscald and rain damage (Hussain et al., 2016; Lin and Agehara, 2018). For viable subtropical blackberry production, dormancy should be artificially released to accelerate budbreak and to advance the fruiting season.

Many chemicals have been tested and developed as dormancy-breaking agents for temperate fruit crops (Ionescu et al., 2016). Various defoliants are commercially applied to promote budbreak and advance flowering time. Among them, the most successful is hydrogen cyanamide (HC). In the past two decades, $\mathrm{HC}$ application has become a major commercial practice in peach (Prunus persica L.) and blueberry (Vaccinium corymbosum $\mathrm{L}$. hybrid) production for breaking bud dormancy in Florida (Olmstead, 2014; Williamson et al., 2002). Although the precise mode of action of $\mathrm{HC}$ is still not fully understood, its various molecular effects have been reported, including increased sublethal oxidative stress, increased production of reactive oxygen species (ROS), auxins, and cytokinins, inhibition of abscisic acid production, upregulation of flowering genes, and downregulation of dormancy-related genes (Ionescu et al., 2016; Sudawan et al., 2016; Tang et al., 2019; Vergara et al., 2012; Yamane et al., 2011). All of these responses also occur naturally during budbreak. The major drawbacks of HC are its adverse health effects and potential environmental pollution (Schep et al., 2009; U.S. Environmental Protection Agency, 2007). As a result, $\mathrm{HC}$ application is 
strictly regulated or even prohibited in some countries. Another useful bud-breaking agent may be gibberellins (GA), which acts as a signal to induce budbreak in many perennial crops (Horvath, 2009). Exogenous $\mathrm{GA}_{3}$ and $\mathrm{GA}_{4}$ induce budbreak in several fruit crops (Donoho and Walker, 1957; Elsabagh, 2014; Tzoutzoukou et al., 1998; Zhuang et al., 2013). In blackberry, although $\mathrm{GA}_{3}$ is effective in inducing budbreak, it causes cultivar-specific flower abortion, making the development of its commercial application challenging (Lin and Agehara, 2020b).

Ideal dormancy-breaking agents should have not only high efficacy but also a favorable safety profile and low application costs. Some fertilizers, such as ZS and urea, are highly effective in defoliating fruit crops (Chapman et al., 1979; Dhillon et al., 2018; Griggs, 1958; Ferguson et al., 2007; Singh et al., 2002). LS is registered as a fungicide for many temperate fruit and nut crops, but its defoliation effects are noted on the product label (e.g., Brandt Lime Sulfur; Brandt Consolidated, Springfield, IL). In addition, budbreak induction effects of defoliants are also reported in many fruit crops. In apricot (Prunus armeniaca $\mathrm{L}$.), $5 \%$ to $10 \%$ of urea and $\mathrm{ZS}$ induced up to $54 \%$ of flower budbreak compared with $12 \%$ in the control (Hegazi, 2012). In sugar apple (Annona squamosa L.), foliar spray of urea at $10 \%$ and $15 \%$ advanced budbreak by 43 and $66 \mathrm{~d}$, flowering by 50 and $72 \mathrm{~d}$, and fruit earliness by 35 and $47 \mathrm{~d}$, respectively (Chander et al., 2019). In cherimoya (Annona cherimola Mill.), foliar spray of urea at $8 \%$ advanced budbreak by 3 weeks, flowering by 2 weeks, and fruit earliness by 12 d (González et al., 2013). However, the efficacy of these defoliants in breaking bud dormancy has not been reported in blackberry.

The development of artificial dormancybreaking methods could help not only establish the subtropical blackberry industry but also cope with future loss of winter chill in temperate climates caused by global warming (Luedeling et al., 2011). The objective of this study was to examine the effects of defoliants on defoliation, budbreak, yields, and fruit quality of 'Natchez' floricanefruiting blackberry under subtropical climatic conditions.

\section{Materials and Methods}

Experiment site and plant material. Two field experiments were conducted at a commercial blackberry farm located in Plant City, FL, the United States (lat. $28^{\circ} 03^{\prime} \mathrm{N}$, long. $82^{\circ} 19^{\prime} \mathrm{W}$, elevation $39 \mathrm{~m}$ ) in the 2018 19 and 2019-20 seasons. The farm was established with tissue-cultured seedlings of 'Natchez' floricane-fruiting blackberry in Spring 2015. The estimated chilling requirement of this cultivar is $\approx 300 \mathrm{~h}$ (McWhirt, $2017 \mathrm{~b}$ ). Plants were grown on raised beds covered with black landscape fabric, and they were spaced at $0.9 \mathrm{~m}$ within a row and $3.6 \mathrm{~m}$ between rows (3237 plant/ha). Canes were trained to a three-wire vertical trellis, with upper, middle, and lower wires positioned at $1.4,0.9$, and $0.4 \mathrm{~m}$ from the ground, respectively. Primocanes were tied to the trellis and trained to loop down when they reached the upper wire. Once primocanes reached the lower wire, they were tipped to encourage lateral growth. Floricanes were pruned in late June immediately after the final harvest. The number of accumulated chilling hours below $7.2{ }^{\circ} \mathrm{C}$ recorded at the experiment site was obtained from the Florida Automated Weather Network (http://agroclimate.org/tools/ Chill-Hours-Calculator/).

Defoliant treatment and experiment design. All treatments were performed between 9:00 and 11:00 AM using a $\mathrm{CO}_{2}$-pressured backpack sprayer (model T; Bellspray, Opelousas, LA) equipped with two flat nozzle tips (XR8002; TeeJet Technologies, Wheaton, IL) spaced $0.46 \mathrm{~m}$ apart on the spray boom. The spray volume was $1870 \mathrm{~L} \cdot \mathrm{ha}^{-1}$. In the 2018-19 season, ZS, KTS, urea, and LS (Brandt Lime Sulfur) were sprayed at $187 \mathrm{~kg} \cdot \mathrm{ha}^{-1}(10 \%, \mathrm{w} / \mathrm{w})$ on 27 Dec. 2018 (the beginning of chill accumulation). In the 2019-20 season, the same defoliant treatments were performed on 25 Dec. 2019, except for KTS, which caused severe phytotoxicity in the 2018-19 season. A nonionic surfactant (Agri-Dex; Helena Chemical, Collierville, $\mathrm{TN})$ was added at $0.5 \%(\mathrm{v} / \mathrm{v})$ to all defoliant treatments including the water control.

In the 2018-19 season, treatments included the control and four defoliants: ZS, KTS, urea, and LS. The experiment was conducted as an incomplete unbalanced randomized block design with three blocks. All treatments had three replicated plots (one plot per block), except that the LS treatment had two replicated plots. Each plot consisted of three to five plants. In the 2019-20 season, treatments included the control and three defoliant treatments: ZS, urea, and LS. All treatments had five replicated plots arranged in a complete randomized design. Each plot consisted of three to five plants.

Defoliation and budbreak. Five representative floricanes were selected per plot before defoliant treatments ( $3-5$ plants per plot). For each cane, a section containing 20 nodes, starting with the third node from the cane tip, was labeled to monitor defoliation and budbreak. The number of nodes without leaves or with sprouted buds was counted on a mostly weekly basis. Buds were considered sprouted when the emergence of green tissue was visible. The percentage of defoliation was calculated by dividing the number of nodes without leaves by 20 and multiplying by 100 . The percentage of budbreak was calculated by dividing the number of nodes with sprouted buds by 20 and multiplying by 100 .

Marketable yield and fruit quality. In the 2018-19 season, fully ripe berries were harvested 13 times between 9 Apr. and 18 June 2019: six times in April, four times in May, and three times in June. In the 2019-20 season, fully ripe berries were harvested 16 times between 1 Apr. and 11 June 2020: five times in April, eight times in May, and three times in June. April, May, and June yields were considered early, mid-, and late-season yields, respectively. We graded harvested berries according to the USDA grade standards (USDA, 2016). Both U.S. No. 1 and U.S. No. 2 berries were considered marketable.

To assess fruit quality, the four largest (by weight) marketable berries were sampled per plot during three and four peak harvests in the 2018-19 and 2019-20 seasons, respectively. For each berry, we recorded fresh weight, length, and width. We measured soluble solids concentration (SSC) using a digital refractometer (PAL-1; ATAGO, Tokyo, Japan) on unfiltered juice. Fruit juice was squeezed from the entire berry with a stainless-steel garlic press.

Statistical analysis. All data were analyzed by the generalized linear mixed model procedure (PROC GLIMMIX) in the SAS statistical software (SAS 9.4; SAS Institute Inc., Cary, NC). Because treatments and experimental design were different between the two seasons, statistical analysis was performed within each season. In the 2018 19 season, treatments were considered a fixed factor, whereas blocks were considered a random factor. In the 2019-20 season, treatments were considered as a fixed factor, and no random effects were considered.

Marketable yield and berry size (e.g., berry fresh weight, length, and width) data were modeled with the lognormal distribution (DIST=LOGNORMAL) and the normal distribution (DIST=NORMAL), respectively. For model parameter estimation, boundary constraints on covariance were removed (NOBOUND), and df for the fixed effects were adjusted by using the Kenward-Roger df approximation (DDFM=KR). Fruit SSC data were modeled with the beta distribution (DIST=BETA), and model parameters were estimated by using maximum likelihood estimation with quadrature approximation $(\mathrm{METHOD}=\mathrm{QUAD})$ and default bias-corrected sandwich estimators (EMPIRICAL=MBN).

Defoliation and budbreak data were collected in a repeated measures design and thus subjected to repeated measure analysis. Fixed factors were treatments, time, and treatment $\times$ time in both seasons. Random factors were blocks and block $\times$ treatment in the 2018-19 season and replication $\times$ treatment in the 2019-20 season. When raw data values were equal to $0 \%$, we set them as $1 \%$ before the analysis. Data were then modeled with the beta distribution (DIST=BETA). A covariance structure was specified based on the smallest corrected Akaike information criterion. Model parameters were estimated by using the restricted subject pseudo-likelihood method (METHOD=RSPL), and df for the fixed effects were adjusted by using the KenwardRoger df approximation (DDFM=KR2).

For marketable yield data, log-transformed data were back-transformed by exponentiating the sum of the least square mean and the correction factor (Sprugel, 1983). For defoliation and budbreak data, data were rescaled to the original scale by using the inverse link option (ILINK) in the LSMEANS statement. Least square means comparisons were 
performed using the Tukey-Kramer test. Unless otherwise noted, $P$ values $<0.05$ were considered statistically significant. Back-transformed or rescaled data are reported in this study.

\section{Results}

Defoliation. In the 2018-19 season, defoliation began before defoliant treatments, with the percentage of defoliation ranging from $19.8 \%$ to $23.9 \%$ at $12 \mathrm{~d}$ before treatment (DBT) (Fig. 1). In the control, defoliation increased gradually from $45.1 \%$ at $7 \mathrm{~d}$ after treatment (DAT) to $55.5 \%$ at 43 DAT. All defoliants induced rapid defoliation. At 7 DAT, the urea treatment showed significantly greater defoliation than the control $(45.1 \%$ vs. $85.2 \%$ ). From 19 to 43 DAT, similar trends were observed: the KTS $(92.1 \%$ to $94.7 \%$ ) and urea treatments ( $88.5 \%$ to $89.6 \%$ ) had significantly greater defoliation than the control $(48.4 \%$ to $55.5 \%)$. Although defoliation induced by ZS (71.9\% to $81.7 \%)$ and LS ( $78.6 \%$ to $84.7 \%$ ) was similar to that by KTS and urea, it was not significantly different compared with the control.
In the 2019-20 season, defoliation at 1 DBT was somewhat variable, ranging from $8.5 \%$ to $26.9 \%$ at $1 \mathrm{DBT}$, but no significant difference was detected by the TukeyKramer test (Fig. 1). In the control, defoliation gradually increased from $24.7 \%$ at 6 DAT to $40.2 \%$ at 48 DAT. From 10 to 48 DAT, defoliation remained significantly greater in the ZS $(82.7 \%$ to $91.9 \%)$ and urea treatments $(73.0 \%$ to $84.2 \%)$ than in the control $(27.4 \%$ to $40.2 \%)$. In the LS treatment, defoliation gradually increased up to $69.7 \%$ at 48 DAT, but no significant difference was detected compared with the control.

Budbreak. In the 2018-19 season, we did not observe any budbreak before the defoliant application on 27 Dec. 2018 (data not shown). In the control, budbreak remained low $(\approx 1.2 \%)$ until 33 DAT but increased gradually thereafter, reaching $26.1 \%$ at 78 DAT (Fig. 2). Compared with the control, the onset of budbreak was advanced by urea, LS, and KTS by 24, 24, and $17 \mathrm{~d}$, respectively. At 7 DAT, the urea treatment $(15.6 \%)$ induced budbreak at a higher percentage compared

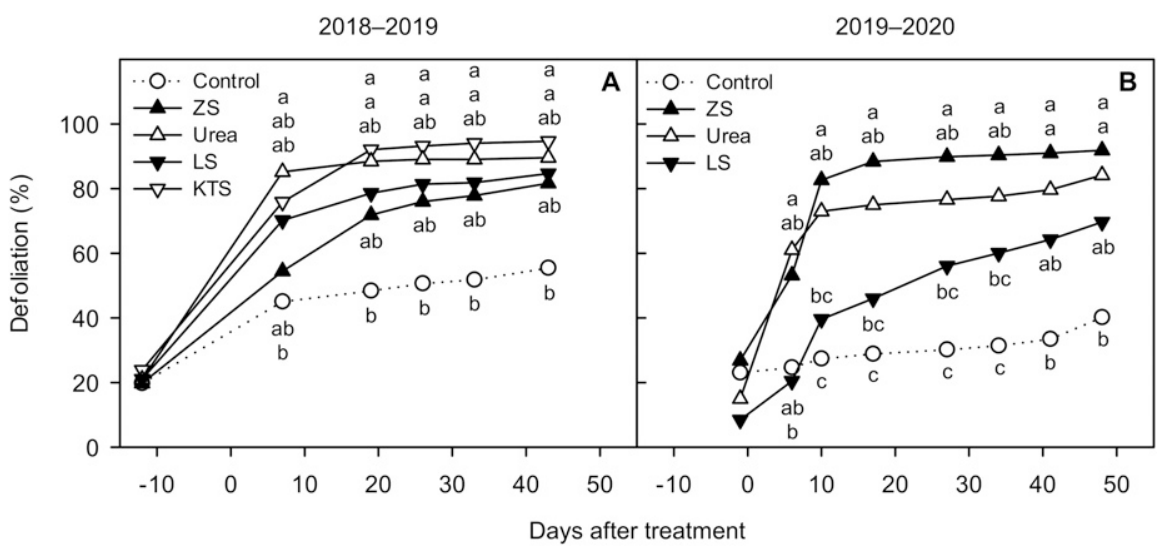

Fig. 1. Defoliation of 'Natchez' blackberry grown under subtropical conditions as affected by defoliants in the (A) 2018-19 and (B) 2019-20 seasons. Plants were treated with defoliants at $187 \mathrm{~kg} \cdot \mathrm{ha}^{-1}$ via spray application (1870 L.ha $\left.{ }^{-1}\right)$ on 27 Dec. 2018 in the 2018-19 season and on 25 Dec. 2019 in the 2019-20 season. A nonionic surfactant (Agri-Dex) was added at $0.5 \%(\mathrm{v} / \mathrm{v})$ to all treatments including the water control. Means ( $\mathrm{n}=2-3$ in the 2018-19 season; $\mathrm{n}=5$ in the 2019-20 season) with the same or no letter within each measurement day are not significantly different (Tukey-Kramer test, $P<0.05$ ). ZS $=$ zinc sulfate; $\mathrm{LS}=$ lime sulfur; KTS = potassium thiosulfate.

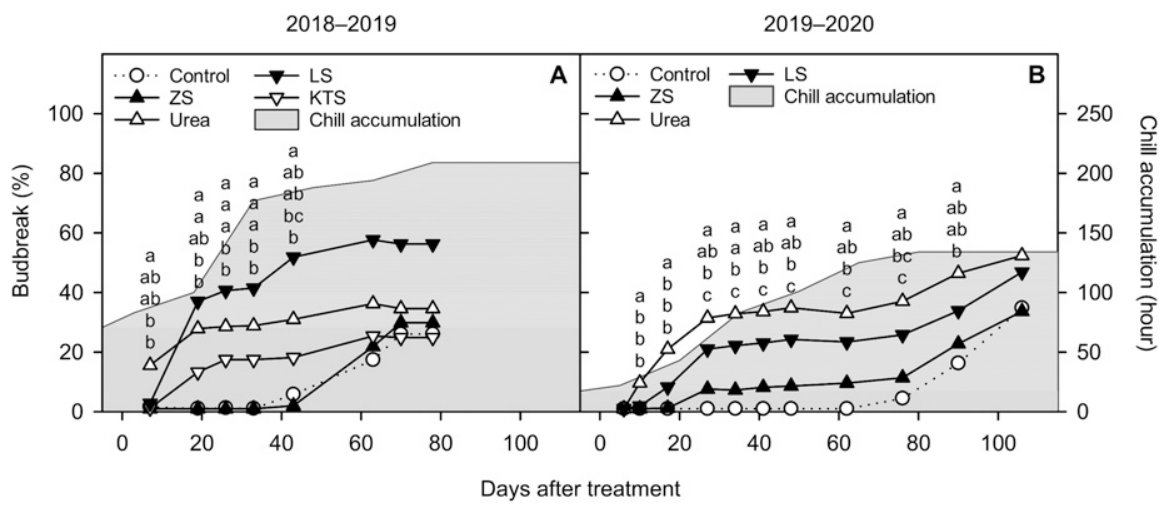

Fig. 2. Budbreak of 'Natchez' blackberry grown under subtropical conditions as affected by defoliants in the (A) 2018-19 and (B) 2019-20 seasons. Treatments and statistical analysis are as described in Fig. 1. $\mathrm{ZS}=$ zinc sulfate; $\mathrm{LS}=$ lime sulfur; KTS = potassium thiosulfate. with the other treatments $(1.0 \%$ to $2.8 \%)$. From 19 through 33 DAT, the KTS (13.3\% to $17.5 \%$ ), urea $(27.9 \%$ to $28.9 \%)$, and LS $(37.0 \%$ to $41.5 \%)$ treatments showed significantly higher percentages of budbreak than the control $(\approx 1.1 \%)$ and the ZS treatment $(1.0 \%)$ (Fig. 3). At 43 DAT, budbreak reached nearly the peak in the LS $(51.9 \%)$, urea $(31.0 \%)$, KTS $(18.2 \%)$ treatments, whereas it was still limited in the ZS treatment $(2.0 \%)$. Thereafter, the ZS treatment showed similar budbreak responses compared with the control, whereas the other defoliant treatments only slightly increased budbreak. As a result, there was no significant difference in budbreak among treatments from 63 through 78 DAT. Although KTS induced rapid budbreak, it caused severe phytotoxicity, including cane dieback and increased bud mortality (Supplemental Fig. 2).

In the 2019-20 season, we did not observe any budbreak before the defoliant application on 25 Dec. 2019 (data not shown). In the control, budbreak remained low $(\approx 1.0 \%)$ until 62 DAT but increased gradually thereafter, reaching $34.8 \%$ at 106 DAT (Fig. 2). Compared with the control, the onset of budbreak was advanced by urea, LS, and ZS by 66, 49, and $49 \mathrm{~d}$, respectively. At 10 and $17 \mathrm{DAT}$, the urea treatment $(9.7 \%$ to $21.0 \%$ ) had significantly higher percentages of budbreak compared with the control $(\approx 1.0 \%)$ and the other defoliant treatments $(1.0 \%$ to $8.3 \%)$. At 27 DAT, all defoliant treatments had significantly higher percentages of budbreak than the control $(1.0 \%)$, and budbreak was induced most rapidly by urea $(31.5 \%)$, followed by LS $(21.0 \%)$ and $\mathrm{ZS}$ (7.6\%). From 34 through 76 DAT, similar trends were observed. Thereafter, budbreak increased again gradually in all defoliant treatments, reaching $33.7 \%$ to $52.4 \%$ at 106 DAT.

Marketable yield. In the 2018-19 season, only early season yield was significantly increased by the defoliant treatments (Table 1 ). Compared with the control $\left(0.12 \mathrm{t} \cdot \mathrm{ha}^{-1}\right)$, urea, KTS, LS, and ZS increased early season yield by $2.79,2.55,0.87$, and $0.31 \mathrm{t} \cdot \mathrm{ha}^{-1}$, respectively. Midseason yield showed no significant difference among the treatments. Late-season yield was reduced in the KTS treatment by $85 \%$ compared with the control, but it showed no significant difference among the other treatments. Compared with the control, total-season yield was $35 \%, 34 \%$, and $16 \%$ higher in the LS, ZS, and urea treatments, respectively, but these increases were not statistically significant.

In the 2019-20 season, the control did not produce any ripe berries in April and thus recorded zero early season yield (Table 1). By contrast, all defoliant treatments produced ripe berries in April (0.15 to 0.29 t.ha ${ }^{-1}$ ). Similar to the 2018-19 season, early season yield was highest in the urea treatment, followed by the LS and ZS treatments. Midseason yield was $101 \%$ higher in the LS treatment than the control at $P<0.10(2.32$ vs. $\left.4.67 \mathrm{t} \cdot \mathrm{ha}^{-1}\right)$. Compared with the control, total-season yield was $87 \%, 85 \%$, and $17 \%$ higher in the urea, LS, and ZS treatments, 


\section{Defoliation (7 DAT)}
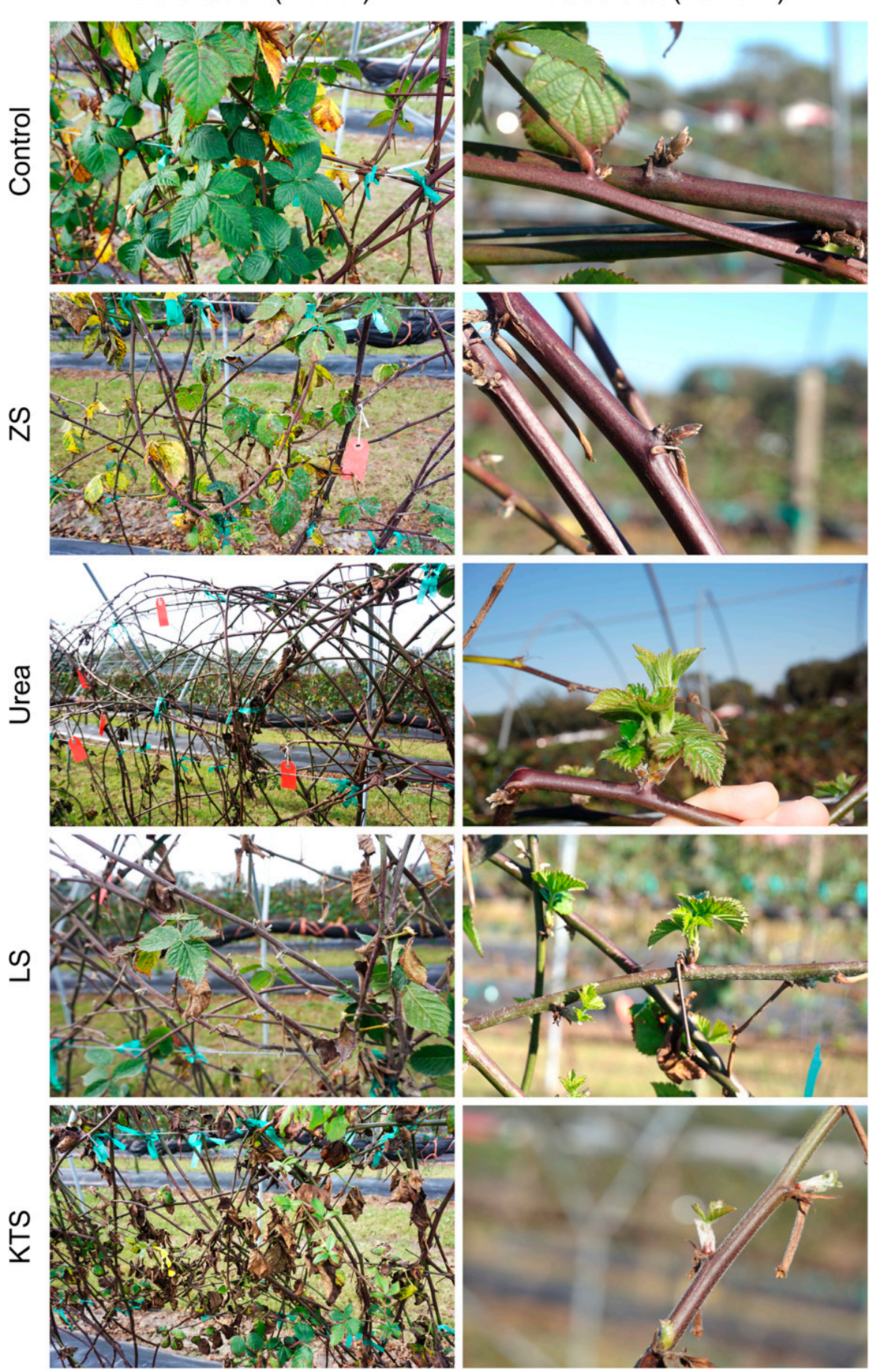

Fig. 3. Defoliation and budbreak of 'Natchez' blackberry grown under subtropical conditions as affected by defoliants in the 2018-19 season. Leaf and bud photographs were taken at 7 and $19 \mathrm{~d}$ after treatment (DAT), respectively. Treatments are as described in Fig. 1. ZS = zinc sulfate; LS = lime sulfur; KTS = potassium thiosulfate.

respectively, but these increases were not statistically significant.

Berry size and quality. In both seasons, no significant treatment effect was detected in berry size (fresh weight, length, and width) and SSC (Table 2).

\section{Discussion}

Differential induction of defoliation and budbreak by defoliants. The commercial use of defoliants in blackberry production is limited (Strik et al., 2007). Although it is reported that three fertilizers, including urea, ammonium sulfate, and copper sulfate, are used as defoliants for 'Brazo' and 'Tupi' blackberry in Mexico (Strik et al., 2007), no published data on the efficacy of defoliants are available. In 'Natchez' blackberry, our results suggest that the effectiveness in inducing defoliation varies among the tested chemicals. Defoliation by LS was moderate, ranging from $69.7 \%$ to $84.7 \%$, whereas more severe defoliation was induced by ZS, urea, and KTS, ranging from $81.7 \%$ to $94.7 \%$. Among the tested chemicals, only urea caused statistically significant defoliation in the two consecutive growing seasons, demonstrating its consistent efficacy as a defoliant for blackberry. The high effectiveness of urea in inducing defoliation is reported in many crops, including sugar apple, guava (Psidium guajava L.), and cherimoya (Chander et al., 2019; Dhillon et al., 2018; González et al., 2013).

Our results also suggest that the effectiveness in promoting budbreak varies among the tested chemicals. Budbreak induction by ZS was minimal, whereas both urea and LS significantly accelerated budbreak in the two consecutive growing seasons. The maximum budbreak observed in this study was $57.7 \%$ in the LS treatment, demonstrating that LS is most effective in promoting budbreak among the tested chemicals. To the best of our knowledge, this is the first work reporting the efficacy of defoliants in promoting defoliation and budbreak of blackberry.

In Mexico, although no published data are available, it has been reported that defoliants are used in combination with GA and thidiazuron during the vegetative growth stage to promote budbreak of 'Brazos', 'Tupy', and other erect blackberry cultivars (Strik et al., 2007). In our study, 'Natchez' was treated only with defoliants at the beginning of chill accumulation. With this method, our results suggest that defoliants alone are highly effective in accelerating budbreak in blackberry.

Potential roles of defoliation in budbreak induction. Interestingly, no clear relationship was found between defoliation and budbreak in this study. For example, ZS induced severe defoliation, but its effect on budbreak was minimal. Conversely, LS induced only moderate defoliation, but its efficacy in promoting budbreak was more pronounced compared with the other chemicals. Unlike ZS and LS, urea and KTS promoted both defoliation and budbreak in a more consistent manner. This observation suggests that defoliation itself does not induce budbreak. A similar observation is reported in a previous study. In apple (Malus domestica Borkh.) grown under inadequate chilling conditions, Díaz et al. (1987) compared the budbreak induction effects of $10 \%$ copper sulfate spray application and manual removal of leaves. They reported $48 \%$ of budbreak in the copper sulfate treatment but only $17 \%$ of budbreak in the manual defoliation treatment.

In temperate fruit crops, warm winter temperatures can result in delayed and incomplete defoliation and budbreak (Walser et al., 1981). One of the important functions of chemical defoliation is to allow floral buds to be receptive to winter chill accumulation, which in turn reduces the depth of dormancy (Lloyd and Firth, 1990; Olmstead, 2015). Early induction of defoliation may help 
Table 1. Marketable yield of 'Natchez' blackberry grown under subtropical conditions as affected by defoliants in the 2018-19 and 2019-20 seasons.

\begin{tabular}{|c|c|c|c|c|c|c|c|c|}
\hline \multirow{2}{*}{ Treatment ${ }^{\mathrm{x}}$} & \multicolumn{8}{|c|}{ Marketable yield (t.ha-1) } \\
\hline & \multicolumn{4}{|c|}{$2018-19^{z}$} & \multicolumn{4}{|c|}{$2019-20^{y}$} \\
\hline Control & $0.12 \mathrm{c}^{\mathrm{w}}$ & 5.30 & $1.76 \mathrm{a}$ & 6.89 & 0.00 & $2.32 \mathrm{~B}^{\mathrm{v}}$ & 1.04 & 3.36 \\
\hline Urea & $2.91 \mathrm{a}$ & 4.17 & $0.74 \mathrm{ab}$ & 7.98 & 0.29 & $4.40 \mathrm{AB}$ & 1.67 & 6.28 \\
\hline LS & $0.98 \mathrm{ab}$ & 7.05 & $1.28 \mathrm{a}$ & 9.31 & 0.18 & $4.67 \mathrm{~A}$ & 1.41 & 6.22 \\
\hline KTS & $2.67 \mathrm{a}$ & 2.37 & $0.26 \mathrm{~b}$ & 5.20 & na & na & na & na \\
\hline$P$ value ${ }^{\mathrm{u}}$ & 0.000 & 0.079 & 0.006 & 0.240 & 0.239 & 0.039 & 0.306 & 0.031 \\
\hline
\end{tabular}

${ }^{\mathrm{z}}$ Early, mid-, and late-season yields represented six harvests in April, four harvests in May, and three harvests in June, respectively.

${ }^{\mathrm{y}}$ Early, mid-, and late-season yields represented five harvests in April, eight harvests in May, and three harvests in June, respectively.

${ }^{\mathrm{x}}$ Treatments are as described in Fig. 1.

${ }^{\mathrm{w}}$ Means ( $\mathrm{n}=2-3$ in the 2018-19 season; $\mathrm{n}=5$ in 2019-20 season) in a column followed by the same letter or no letter are not significantly different (Tukey-Kramer test, $P<0.05$ ).

${ }^{\mathrm{v}}$ Means in a column followed by the same uppercase letter are not significantly different (Tukey-Kramer test, $\left.P<0.10\right)$. Significant differences were not detected at $P<0.05$.

${ }^{\mathrm{u}} P$ values indicate the significance of the treatment effect.

$\mathrm{ZS}=$ zinc sulfate; $\mathrm{LS}=$ lime sulfur; KTS = potassium thiosulfate; na = not available.

Table 2. Berry size and soluble solids concentration (SSC) of 'Natchez' blackberry grown under subtropical conditions as affected by defoliants in the $2018-19$ and 2019-20 seasons.

\begin{tabular}{|c|c|c|c|c|c|c|c|c|}
\hline \multirow[b]{2}{*}{ Treatment ${ }^{x}$} & \multicolumn{4}{|c|}{$2018-19^{z}$} & \multicolumn{4}{|c|}{$2019-20^{y}$} \\
\hline & $\overline{\text { Berry FW (g) }}$ & Berry length $(\mathrm{cm})$ & Berry width $(\mathrm{cm})$ & $\overline{\operatorname{SSC}\left({ }^{\circ} \text { Brix }\right)}$ & Berry FW (g) & Berry length $(\mathrm{cm})$ & Berry width $(\mathrm{cm})$ & SSC ( ${ }^{\circ}$ Brix $)$ \\
\hline ZS & 9.3 & 2.77 & 2.35 & 11.3 & 8.7 & 2.74 & 2.40 & 10.2 \\
\hline LS & 12.3 & 3.21 & 2.55 & 12.1 & 8.0 & 2.54 & 2.38 & 10.4 \\
\hline KTS & 10.4 & 2.97 & 2.40 & 11.0 & na & na & na & na \\
\hline$P$ value ${ }^{\mathrm{w}}$ & 0.175 & 0.401 & 0.128 & 0.543 & 0.151 & 0.052 & 0.524 & 0.272 \\
\hline
\end{tabular}

${ }^{\mathrm{z}}$ Data were collected from five peak harvests between 26 Apr. and 4 June 2019.

${ }^{\mathrm{y}}$ Data were collected from three peak harvests between 18 May and 2 June 2020

${ }^{\mathrm{x}}$ Treatments are as described in Fig. 1.

${ }^{\mathrm{w}} P$ values indicate the significance of the treatment effect.

$\mathrm{ZS}=$ zinc sulfate; $\mathrm{LS}=$ lime sulfur; KTS = potassium thiosulfate; na = not available.

maximize chill accumulation and thus improve budbreak, especially under inadequate chilling conditions. In this study, cumulative chilling hours were 209 and $134 \mathrm{~h}$ in the first and second growing seasons, respectively, more than $60 \%$ of which were recorded after the application of defoliants. Therefore, the promotive effect of urea, KTS, and ZS on budbreak may be due partly to the early induction of defoliation, which in turn increased chill accumulation required for budbreak. However, compared with ZS, urea and KTS promoted budbreak to a greater extent, suggesting that budbreak induction by urea and KTS is facilitated not only by defoliation but also by other mechanisms, such as elevated oxidative stress (Beauvieux et al., 2018; Maleva et al., 2015) and increased tissue nitrogen concentration (Singh et al., 2002; Thitithanakul et al., 2012).

Defoliants improve fruit earliness and change yield distribution. The most pronounced beneficial effect of these defoliants was improved fruit earliness. In central Florida, blackberry harvesting typically starts in mid-May (Lin and Agehara, 2020a). High precipitation and warm temperatures during the late-season harvest (Supplemental Fig. 1) can adversely affect fruit quality by increasing disease damage or causing physiological disorders, such as sunscald and red duplet (Edgley et al., 2019; Lin and Agehara, 2018; McWhirt, 2017a). Therefore, improved fruit earliness by these defoliants may improve not only early season yield but also fruit quality and marketability by avoiding unfavorable weather conditions. In this study, defoliant treatments advanced harvesting by up to 1 month (as early as 1 Apr.) and increased early season yield by 0.31 to $2.79 \mathrm{t} \cdot \mathrm{ha}^{-1}$, demonstrating the effectiveness in improving fruit earliness under inadequate chilling conditions. This improved fruit earliness is due likely to accelerated budbreak. Among the tested chemicals, budbreak was induced most rapidly by urea, followed by LS, KTS, and ZS, advancing by 17 to $66 \mathrm{~d}$ compared with the control. The similar pattern was also observed for early season yield. The high efficacy of urea in inducing budbreak is also reported in tropical fruit crops, in which chill accumulation is not a prerequisite for dormancy release. In sugar apple, foliar spray of urea at $10 \%$ advanced budbreak by $43 \mathrm{~d}$, flowering by $50 \mathrm{~d}$, and fruit ripening by $35 \mathrm{~d}$, respectively (Chander et al., 2019). In cherimoya, foliar spray of urea at $8 \%$ advanced budbreak by 3 weeks, flowering by 2 weeks, and fruit ripening by $12 \mathrm{~d}$ (González et al., 2013). Therefore, the promotive effect of urea on budbreak could be independent of chilling requirements. The mechanism of budbreak induction by urea may partly involve increased ROS production, which is reported to play an important role in dormancy release in temperate fruit crops (Beauvieux et al., 2018). In fact, increased ROS production is considered one of the modes of action of HC in breaking bud dormancy (Liang et al., 2019; Pérez et al., 2008; Sudawan et al., 2016; Tang et al., 2019).

It is interesting to note that, in the first growing season, ZS increased early season yield by $0.31 \mathrm{t} \cdot \mathrm{ha}^{-1}$ compared with the control, although it did not advance the onset of budbreak. It is possible that ZS may have promoted budbreak after the measurement period. However, this possibility does not apply to our early season yield data, because 1) it typically takes $\approx 60 \mathrm{~d}$ from budbreak to fruit ripening in 'Natchez' (Lin and Agehara, 2020a), 2) the last budbreak measurement was performed on 15 Mar., and 3) early season yield data were collected from 9 Apr. through 30 Apr. Another explanation is that ZS may promote downstream responses after budbreak, such as flower and fruit development. In apple, Zhang et al. (2016) reported that the combined application of ZS and urea before budbreak increased the activities of carbohydrate metabolism-related enzymes in fruit tissues compared with the urea treatment. The metabolic changes caused by zinc may explain the result that $\mathrm{ZS}$ improved fruit earliness without promoting budbreak.

In contrast to early season yield, increases in total-season yield by defoliants were relatively small and nonsignificant. These results were due to the change in yield distribution. In the first growing season, for example, early season yield in the control and the urea treatment accounted for $2 \%$ and $36 \%$ 
of total-season yield, respectively. Therefore, the spray application of defoliants in late December (the beginning of the winter chill period at this experiment site) appears to be an effective strategy to improve fruit earliness, rather than total-season yield.

Practical implications. A single spray application of urea, LS, or ZS at the beginning of chill accumulation increased early season yield by 0.31 to $2.79 \mathrm{t} \cdot \mathrm{ha}^{-1}$, compared with the control $\left(0.12 \mathrm{t} \cdot \mathrm{ha}^{-1}\right)$. Although not statistically significant, it also increased total-season yield by $16 \%$ to $87 \%$. By contrast, KTS is not a suitable defoliant for blackberry because of its phytotoxicity effects. The results in this study suggest that foliar application of urea, LS, or ZS can be an important adaptation tool for subtropical blackberry production. These defoliants have several key features for successful commercial implementation. First, they are all readily available chemicals: ZS and urea are common fertilizers, and LS is a fungicide already registered for use on blackberry. Second, ZS and urea are relatively inexpensive. On the basis of the prices at a local major supplier of agricultural chemicals and the application method used in this study, the application costs of ZS and urea are $\$ 162$ and $\$ 165$ per hectare, respectively, of which $\$ 35$ is for the adjuvant (Agri-Dex). Third, they have no negative side effect on fruit development and quality. Fourth, they have relatively favorable safety profiles compared with hydrogen cyanamide, which is the most widely used dormancy-breaking agent in some fruit crops (Ionescu et al., 2016; Olmstead, 2014; Williamson et al., 2002). Among the three defoliants, urea appears to be the ideal chemical option because of its consistent efficacy, favorable safety profile, and low application cost.

To maximize the final percentage of budbreak, dormancy-breaking agents are often applied when plants accumulate a certain amount of winter chill (Erez, 1995; Sheard et al., 2009). Díaz et al. (1987) measured floral budbreak in apple treated with $10 \%$ urea at different chill accumulation stages in the lowland of northwestern Mexico (lat. $29^{\circ} \mathrm{N}$; elevation $50 \mathrm{~m}$ ). The final percentage of budbreak increased from $25 \%$ to $80 \%$ by delaying urea application from midDecember to early January, suggesting that the efficacy of urea in promoting budbreak depends on the amount of chill accumulation. In this study, defoliants were applied at the beginning of chill accumulation, with the aim of improving fruit earliness. Future studies should also investigate the effect of defoliant application at the end of chill accumulation or near the natural budbreak stage. Although delaying defoliant application will likely lessen its efficacy in improving fruit earliness, it may be more effective in maximizing budbreak and thus total-season yield. Furthermore, delaying defoliant application can avoid the risk of freeze damage on developing flowers. Additional studies are also needed to optimize the application rate of the defoliants.
Under climate change scenarios, the global mean temperature is projected to increase by 1.6 and $6.9^{\circ} \mathrm{C}$ by the end of the $21 \mathrm{st}$ century (Betts et al., 2011). In California, Luedeling et al. (2009) projected that winter chill could be reduced by $50 \%$ to $75 \%$ by the mid-21st century. Therefore, the development of dormancy-breaking agents could help not only establish the subtropical blackberry industry but also cope with future loss of winter chill caused by global warming in the temperate blackberry industry.

\section{Literature Cited}

Atkinson, C.J., R.M. Brennan, and H.G. Jones. 2013. Declining chilling and its impact on temperate perennial crops. Environ. Exp. Bot. 91:48-62, doi: 10.1016/j.envexpbot.2013.02. 004 .

Beauvieux, R., B. Wenden, and E. Dirlewanger. 2018. Bud dormancy in perennial fruit tree species: A pivotal role for oxidative cues. Front. Plant Sci. 9:657, doi: 10.3389/fpls.2018. 00657.

Betts, R.A., M. Collins, D.L. Hemming, C.D Jones, J.A. Lowe, and M.G. Sanderson. 2011. When could global warming reach $4^{\circ} \mathrm{C}$ ? Philos. Trans. R. Soc. A Math. Phys. Eng. Sci. 369:6784, doi: 10.1098/rsta.2010.0292.

California Strawberry Commission. 2019. Retail category trends report. $21 \mathrm{Sept} .2020 .<\mathrm{https} / / /$ www.calstrawberry.com/en-us/market-data/ retail-category-trends $>$.

Carter, P.M., J.R. Clark, C.D. Particka, and D.Y. Crowne. 2006. Chilling response of Arkansas blackberry cultivars. J. Amer. Pomol. Soc. 60:187-197.

Chander, S., K.K. Upreti, and L. Hunashikatti. 2019. Chemical interventions for advancing the fruiting season of sugar apple (Annona squamosa L.) cv. balanagar. Intl. J. Chem. Stud. 7:774-781.

Chapman, K.R., J. Saranah, and B. Paxton. 1979. Induction of early cropping of guava seedlings in a closely planted orchard using urea as a defoliant. Austral. J. Expt. Agr. 19:382-384, doi: 10.1071/EA9790382.

Clark, J.R. and C.E. Finn. 2014. Blackberry cultivation in the world. Rev. Bras. Frutic. 36:4657, doi: 10.1590/0100-2945-445/13.

Dhillon, J.S., R.S. Boora, D.S. Gill, and N.K. Arora. 2018. Effect of different chemicals and hand thinning on crop regulation in guava (Psidium guajava L.) cv. Shweta. Agr. Res. J. 55:365-369, doi: 10.5958/2395-146X.2018. 00067.4.

Díaz, D.H., A. Alvarez, and J. Sandoval. 1987. Cultural and chemical practices to induce uniform bud break of peach and apple under warm climates in Mexico. Acta Hort. 199:129-136, doi: 10.17660/ActaHortic.1987.199.31.

Donoho, C.W. and D.R. Walker. 1957. Effect of gibberellic acid on breaking of rest period in Elberta peach. Science 126:1178-1179.

Drake, C.A. and J.R. Clark. 2000. Determination of the chilling requirement of Arkansas thornless blackberry cultivars. Student J. Dale Bump. Coll. Agr. Food Life Sci. 1:30-32.

Edgley, M., D.C. Close, and P.F. Measham. 2019. Effects of climatic conditions during harvest and handling on the postharvest expression of red drupelet reversion in blackberries. Scientia Hort. 253:399-404, doi: 10.1016/j. scienta.2019.04.052.

Elsabagh, A.S. 2014. Influences of potassium nitrate, gibberellin and benzyl adenine on bud break, fruit set and branch induction of almond trees. Acta Hort. 1028:359-366, doi: 10.17660/ ActaHortic.2014.1028.58.

Erez, A. 1995. Means to compensate for insufficient chilling to improve bloom and leafing. Acta Hort. 395:81-95, doi: 10.17660/ActaHortic. 1995.395.7.

Fear, C.D. and M.-D.L. Meyer. 1993. Breeding and variation in Rubus germplasm for low winter chill requirement. Acta Hort. 352:295-304, doi: 10.17660/ActaHortic. 1993.352.42.

Ferguson, J., J. Chaparro, J. Williamson, R. Rouse, and R. Mizell. 2007. Florida subtropical peaches: Production practices. 19 Nov. 2018. <https:// journals.flvc.org/edis/article/view/117046>.

González, M., J.J. Hueso, F. Alonso, and J. Cuevas. 2013. Foliar application of urea advances bud break, bloom and harvest in cherimoya (Annona cherimola Mill.). Acta Hort. 975:269-274, doi: 10.17660/ActaHortic.2013.975.30.

Griggs, W.H. 1958. Defoliation for early pruning. Califonia Agr. (September):12-15.

Hegazi, A.A. 2012. Effects of some dormancy breaking agents on flowering, fruiting and fruit characteristics of 'Canino' apricot cultivar. World J. Agr. Sci. 8:169-173.

Horvath, D. 2009. Common mechanisms regulate flowering and dormancy. Plant Sci. 177:523531, doi: 10.1016/j.plantsci.2009.09.002

Hussain, I., S.R. Roberto, I.C.B. Fonseca, A.M. deAssis, R. Koyama, and L.E.C. Antunes. 2016. Phenology of 'Tupy' and 'Xavante' blackberries grown in a subtropical area. Scientia Hort. 201:78-83, doi: 10.1016/j.scienta. 2016.01.036.

Ionescu, I.A., B.L. Møller, and R. Sánchez-Pérez. 2016. Chemical control of flowering time. J. Expt. Bot. 68:369-382, doi: 10.1093/jxb/erw427.

Liang, D., X. Huang, Y. Shen, T. Shen, H. Zhang, L. Lin, J. Wang, Q. Deng, X. Lyu, and H. Xia. 2019. Hydrogen cyanamide induces grape bud endodormancy release through carbohydrate metabolism and plant hormone signaling. BMC Genomics 20:1-14, doi: 10.1186/s12864-0196368-8.

Lin, S.-Y. and S. Agehara. 2018. Phenology, yield and fruit quality of floricane-fruiting blackberry cultivars under high tunnel and net house production systems in Florida. Proc. Annu. Meet. Fla. State Hort. Soc. 131:13-16.

Lin, S.-Y. and S. Agehara. 2020a. Exogenous gibberellic acid advances reproductive phenology and increases early-season yield in subtropical blackberry production. Agronomy 10:1317, doi: 10.3390/agronomy10091317.

Lin, S.-Y. and S. Agehara. 2020b. Exogenous gibberellic acid and cytokinin effects on budbreak, flowering, and yield of blackberry grown under subtropical climatic conditions. HortScience 55:1938-1945, doi: 10.21273/HORTSCI 15381-20.

Lloyd, J. and D. Firth. 1990. Effect of defoliation time on depth of dormancy and bloom time for low-chill peaches. HortScience 25:1575-1578.

Luedeling, E., E.H. Girvetz, M.A. Semenov, and P.H. Brown. 2011. Climate change affects winter chill for temperate fruit and nut trees. PLoS One 6:e20155, doi: 10.1371/journal. pone. 0020155 .

Luedeling, E., M. Zhang, and E.H. Girvetz. 2009 Climatic changes lead to declining winter chill for fruit and nut trees in California during 1950-2099. PLoS One 4:e6166, doi: 10.1371/journal.pone.0006166.

Maleva, M., G. Borisova, N. Chukina, and M.N.V. Prasad. 2015. Urea-induced oxidative damage in Elodea densa leaves. Environ. Sci. Pollut. 
Res. Int. 22:13556-13563, doi: 10.1007/s11356015-4600-x.

McWhirt, A. 2017a. What is going on with my blackberry fruit? Identifying blackberry fruit disorders. 21 May 2018. <https://www.uaex. edu/farm-ranch/crops-commercial-horticulture/ horticulture/ar-fruit-veg-nut-update-blog/posts/ fruitdisorders.aspx $>$.

McWhirt, A. 2017b. Blackberry variety selection. 20 Nov. 2020. <https://www.uaex.edu/farmranch/crops-commercial-horticulture/horticulture/ commercial-fruit-production/blackberry-school. aspx>.

Olmstead, M. 2014. Application of hydrogen cyanamide to increase bloom uniformity in lowchill peaches: A preliminary report. Proc. Annu. Meet. Fla. State Hort. Soc. 127:18-20.

Olmstead, M. 2015. Defoliating peaches. 17 Sept. 2015. <https://crec.ifas.ufl.edu/extension/trade_ journals/2015/2015_September_peaches.pdf $>$.

Pérez, F.J., R. Vergara, and S. Rubio. 2008. $\mathrm{H}_{2} \mathrm{O}_{2}$ is involved in the dormancy-breaking effect of hydrogen cyanamide in grapevine buds. Plant Growth Regulat. 55:149-155, doi: 10.1007/ s10725-008-9269-4.

Schep, L., W. Temple, and M. Beasley. 2009. The adverse effects of hydrogen cyanamide on human health: An evaluation of inquiries to the New Zealand National Poisons Centre. Clin. Toxicol. 47:58-60, doi: 10.1080/ 15563650802459254.

Sheard, A.G., S.D. Johnson, and N.C. Cook. 2009. Effect of timing and concentration of rest breaking agents on budburst in 'Bing' sweet cherry under conditions of inadequate winter chilling in South Africa. S. Afr. J. Plant Soil 26:73-79, doi: 10.1080/02571862.2009. 10639937.

Singh, G., A.K. Singh, S. Rajan, and S.R. Bhriguvanshi. 2002. Strategy for crop regulation in guava (Psidium guajava L.) through foliar urea sprays and its effect on different
$\mathrm{N}$-forms in leaves. J. Appl. Hort. 04:93-98, doi: 10.37855/jah.2002.v04i02.26.

Sprugel, D.G. 1983. Correcting for bias in logtransformed allometric equations. Ecology 64:209-210, doi: 10.2307/1937343.

Strik, B.C., J.R. Clark, C.E. Finn, and M.P. Bañados. 2007. Worldwide blackberry production. HortTechnology 17:205-213, doi: 10.21273/HORTTECH.17.2.205.

Sudawan, B., C.S. Chang, H.F. Chao, M.S.B. Ku, and Y.F. Yen. 2016. Hydrogen cyanamide breaks grapevine bud dormancy in the summer through transient activation of gene expression and accumulation of reactive oxygen and nitrogen species. BMC Plant Biol. 16:1-18, doi: 10.1186/s12870-016-0889-y.

Takeda, F., B.C. Strik, D. Peacock, and J.R. Clark. 2002. Cultivar differences and the effect of winter temperature on flower bud development in blackberry. J. Amer. Soc. Hort. Sci. 127:495-501.

Tang, L., S. Chhajed, T. Vashisth, M.A. Olmstead, J.W. Olmstead, and T.A. Colquhoun. 2019. Transcriptomic study of early responses to the bud dormancy-breaking agent hydrogen cyanamide in 'TropicBeauty' peach. J. Amer. Soc. Hort. Sci. 144:244-256, doi: 10.21273/JASHS 04686-19.

Thitithanakul, S., G. Ṕtel, M. Chalot, and F. Beaujard. 2012. Supplying nitrate before bud break induces pronounced changes in nitrogen nutrition and growth of young poplars. Funct. Plant Biol. 39:795-803, doi: 10.1071/FP12129.

Tzoutzoukou, C.G., C.A. Pontikis, and A. ToliaMarioli. 1998. Effects of gibberellic acid on bloom advancement in female pistachio (Pistacia vera L.). J. Hort. Sci. Biotechnol. 73:517526, doi: 10.1080/14620316.1998.11511008.

U.S. Department of Agriculture. 2016. United States standards for grades of dewberries and blackberries. 19 Apr. 2019. <https://www.ams. usda.gov/sites/default/files/media/Dewberries BlackberriesStandard.pdf $>$.
U.S. Department of Agriculture. 2017. USDA/ NASS Quickstats Ad-Hoc Query Tool. 8 July 2019. <https://quickstats.nass.usda.gov/results/ 08D195DC-7B67-32E7-9167-4314A69E6E69>.

U.S. Environmental Protection Agency. 2007. Ecological risk assessment problem formulation for: Cyanamide. U.S. Environmental Protection Agency, Washington, DC.

Vergara, R., S. Rubio, and F.J. Pérez. 2012. Hypoxia and hydrogen cyanamide induce budbreak and up-regulate hypoxic responsive genes (HRG) and $V v F T$ in grapevine-buds. Plant Mol. Biol. 79:171-178, doi: 10.1007/ s11103-012-9904-3.

Walser, R.H., D.R. Walker, and S.D. Seeley. 1981. Effect of temperature, fall defoliation and gibberellic acid on the rest period of peach buds. J. Amer. Soc. Hort. Sci. 106:91-94.

Williamson, J.G., G. Krewer, B.E. Maust, and E.P. Miller. 2002. Hydrogen cyanamide accelerates vegetative budbreak and shortens fruit development period of blueberry. HortScience 37:539-542, doi: 10.21273/hortsci.37.3.539.

Yamane, H., T. Ooka, H. Jotatsu, Y. Hosaka, R. Sasaki, and R. Tao. 2011. Expressional regulation of PpDAM5 and PpDAM6, peach (Prunus persica) dormancy-associated MADS-box genes, by low temperature and dormancybreaking reagent treatment. J. Expt. Bot. 62:3481-3488, doi: 10.1093/jxb/err028.

Zhang, Y., Y. Yan, C. Fu, M. Li, and Y. Wang. 2016. Zinc sulfate spray increases activity of carbohydrate metabolic enzymes and regulates endogenous hormone levels in apple fruit. Scientia Hort. 211:363-368, doi: 10.1016/j. scienta.2016.09.024.

Zhuang, W., Z. Gao, L. Wang, W. Zhong, Z. Ni, and Z. Zhang. 2013. Comparative proteomic and transcriptomic approaches to address the active role of $\mathrm{GA}_{4}$ in Japanese apricot flower bud dormancy release. J. Expt. Bot. 64:49534966, doi: $10.1093 / \mathrm{jxb} / \mathrm{ert} 284$. 


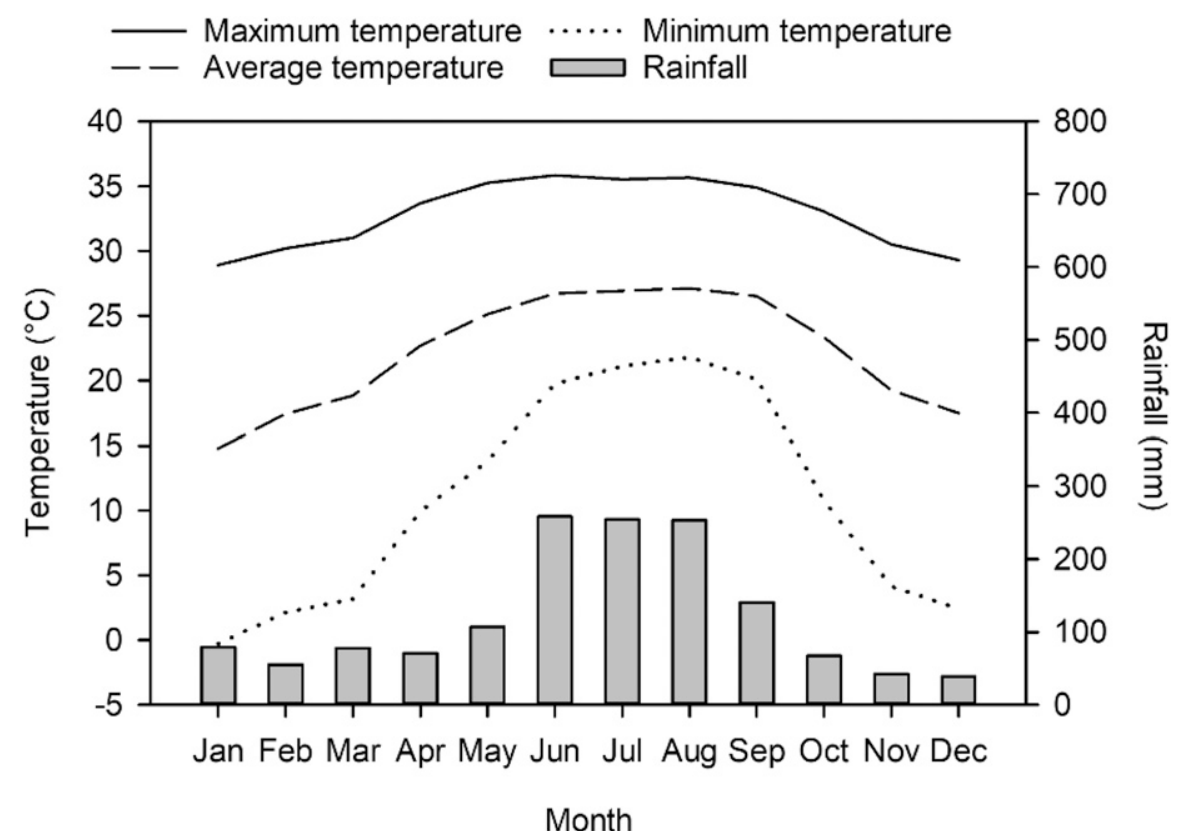

Supplemental Fig. 1. Monthly average temperature and rainfall near the experiment site in Dover, FL, in the United States from 2010 to 2019. The weather station is located $19 \mathrm{~km}$ from the experiment site.

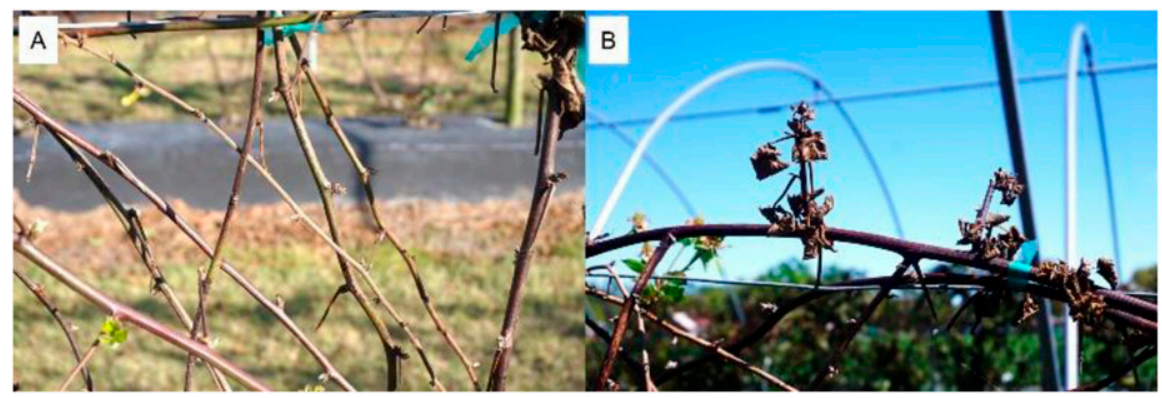

Supplemental Fig. 2. (A) Cane dieback and (B) damage in flower buds caused by potassium thiosulfate. 